\title{
Local Environment
}

The International Journal of Justice and Sustainability

ISSN: 1354-9839 (Print) 1469-6711 (Online) Journal homepage: http://www.tandfonline.com/loi/cloe20

\section{(Local-) community for global challenges: carbon conversations, transition towns and governmental elisions}

\section{Gerald Taylor Aiken}

To cite this article: Gerald Taylor Aiken (2015) (Local-) community for global challenges: carbon conversations, transition towns and governmental elisions, Local Environment, 20:7, 764-781, DOI: $10.1080 / 13549839.2013 .870142$

To link to this article: http://dx.doi.org/10.1080/13549839.2013.870142

曲 Published online: 21 Jan 2014.

Submit your article to this journal $₫$

Џll Article views: 762

Q View related articles $\llbracket$

View Crossmark data $\nearrow$

Citing articles: 2 View citing articles 


\title{
(Local-) community for global challenges: carbon conversations, transition towns and governmental elisions
}

\author{
Gerald Taylor Aiken*
}

St. John's College, Durham University, Durham DH1 3RJ, UK

(Received 5 May 2012; accepted 10 November 2013)

\begin{abstract}
This article addresses the narrowing interpretation of community when governmentalised: that of community's elision with local. First it surveys five broad academic and policy interpretations of the community implied in low carbon transitions. These demonstrate the persistence of community's broad and open-ended polysemy today. Second it looks more closely at the role community plays in UK environmental governance today, including specific evidence from two such government-funded community initiatives used to meet global environmental challenges: Transition Towns and Carbon Conversations. Third it provides a critique of community governance-beyond-the-state. It argues that community used to "jump scales" in response to global challenges like climate change, is often at its most narrow: local and governmentalised. Doing so helps contextualise the governmentalisation of (local-) community in UK environmental governance. Often it is localised in order to delegate (perceived) agency and responsibility onto individual actors at a local level.
\end{abstract}

Keywords: community; transition; localism; transition towns; governmentality

\section{Local community for global challenges}

"Community's" emergence as a site of response to global challenges has a distinctly local tinge. This flow from the global challenge of climate change to community as a key expression in response, to community's implicit implication in the local leads us very far from global. This "jumping scales" (Smith 1984) is not to reassert some outmoded binary of local-global, but rather to highlight the chain of implication. Seeing local as distinct from global is no longer possible, as geographers have long argued. Global challenges are locally produced, and so too are their "solutions". Massey calls this the "local production of the global" (2005, p. 102).

Climate change also questions any merit in separating the global from the local. Hulme writes of the "metrological entanglement" $(2009$, p. 3) of global climate and local weather patterns. Macnaghten (2006) highlights the way in which climate change narratives have shifted from remote global conceptions to specific localised ones - think of the whiteness of the Arctic, to the oft-repeated computer generated photo of a flooded low-lying London imagined some years hence. In these, it becomes impossible to disentangle local from global in production of, or responsibility for, environmental bads. This adopts a

\footnotetext{
*Email: gerald.aiken@durham.ac.uk
} 
cosmopolitan - as Beck (2006) would put it - approach to climatic and global challenges. It mirrors that which has previously been worked out by geographers and other spatial theorists, thinking about place, and the mutual embeddedness and co-production entailed in what can uncritically be called "local" or "global". These are not just theoretical points; the environmental movement has also drawn attention to the responsibility felt in any given locality to those distant in space and time (Hulme 2010). Think of the popular slogan: "Think Global, Act Local".

"Community" emerges as a key site in the transition to low carbon futures partly because of its ability to encompass both the global and local, and also to internalise and governmentalise the behavioural changes that transition to low carbon futures requires. Yet the way "community" is invoked often pushes agency and responsibility on individuals at a local level, in everyday lives, taking a specific governmentalised tone. The polysemy of "community", its great virtue and frustration, only cuts one way. "Community" when it appears in government policy is local, yet this local community can be put to all manner of uses - even global challenges like climate change.

As Massey pointed out regularly: "geography matters", firmly arguing that the way we think about space and spatiality is not abstract speculation, but has all-too-important real world implications;similarly "community". "Community", its elision with the local, its increasing use as a site of response to global issues, and the prior presumptions we bring to and with it, then have implications that ought to be questioned. The wide and varied understanding of community is only local in government policy. Expressions of community such as "epistemic communities" (Lovell and Mackenzie 2000) are overlooked. When words/concepts are used as uncritically, apolitically, or even as "never used unfavourably" (Williams 1983, p. 76) as "community" has been in this context, the danger is that other political agendas can use this. Community is deployed differently. As polysemic it bridges both the global and local - why is community narrowed when governmentalised?

Two projects here - Carbon Conversations and Transition Towns - seek to use "community" values, strongly rooted in local places to alter environmental behaviours. Government funding for these projects - in this case from the Scottish Government's Climate Challenge Fund (CCF) - does not just determine that a certain version of "community" is chosen, encouraged and funded. It also ensures that (local-) community itself is something to aim for, worth mentioning for a successful funding application. This is not coincidental. In this case it reflects deliberate policy from the Scottish National Party (supported by Scottish Green Party) to stipulate that the funding must come from "local community groups". National NGOs like Friends of the Earth Scotland, who may have pioneered very similar initiatives, were excluded. The belief being that the more local the communities, the more local the decision-making that was devolved and the more effective the money would be (Stewart et al. 2013).

This use of "community" is problematic for a number of reasons. As Amin points out: "the idea of government by community ... can lead to unrealistic and excessively high ... expectations laid at the doorstep of local community" (2005, p. 624). Words written in 2005 could refer today to the narratives around New Localism, Big Society, or "new parochialism" (Featherstone 2013, p. 51). A community ambitious enough to meet global issues while also being humble enough to expect only incremental, small-scale change is problematic. Power narratives latent within this elision of local and "community" can be critiqued. If it is indeed the case that "local communities" are expected to take on the responsibility for and ability to respond to major challenges like climate change, then surely there is a need to look again at the role "community" plays in combating climate change. That such a term is 
universally seen as unswervingly positive should not be taken as a given then, and should offer pause for thought.

This paper comes in three sections. First, it addresses the wide variety and application of "community" in government policy and recent academic literature. Increasingly, as community is expected to respond to climate change, the form of community has narrowed from initial polysemy. There then follows a brief outline of two empirical examples of how this state-funded community looks on the ground: Transition Towns and Carbon Conversations, both funded by the Scottish Government's CCF. Finally it offers critique of governmentbeyond-the-state, particularly the "community" implicated.

\section{2. "Community": a palate of five flavours}

"Community" can be seen as either a collective whole, as the aggregate of a collection of individuals, or as a particular collection, small-scale or area. However it is used, community holds a special place. ${ }^{1}$ Whenever it is used, it is more than just a group or place and yet does contain both these ideas. Recently, community has been seen as an area of untapped research with potential to meet the required transition to a low carbon future (CSE 2007, Jackson 2009, IPPR 2010, 2011, RSA 2010, Hopkins 2011). This paper now introduces the various schools of literature that have brought the concept of community to bear in this area, and assess how they understand community. Each of these has talked of the role community can play in the transition towards low carbon futures. Yet each understands community differently. What does each presume about community?

\section{1. “Community" in the multi-level perspective}

One of the most influential ways to understand the transition to low carbon comes from science and technology studies (STS), and is through the lens of the multi-level perspective (MLP) (Rip and René 1998). Here community is a niche. The literature here is wide and varied, but three broad groupings can be identified. First seeing community as a niche or niche-innovation comes from the mainstream MLP literature, sometimes called Transition Management. Second, seeing community as a social innovation, uses MLP theory, but offers a "friendly critique" of it, and seeks to integrate synergistic conceptual material from social practice theory and is less technologically focused. Third, seeing community as a grassroots innovation again is a critical friend of MLP, this time widening the net to include more alternative practices. It is bottom-up, whereas the previous two interpretations could theoretically be imposed through government initiatives or corporate R\&D schemes.

\section{2. “Community” as a niche(-innovation)}

The MLP has three levels. At the bottom, micro-level, we have niches, or "niche-innovations" (Geels and Schot 2007, p. 399). Niches are defined as unconventional and create enterprising technologies and practices. Because of their unconventionality, they are sites of innovation, but also limited in their scope, they are by their nature "small and unstable", "novelties" (Geels and Schot 2007, p. 400, 402). The meso-level consists of a patchwork of regimes; these being more stable, operating on a larger scale than niches. Regimes encompass a higher level than niches and as such take in a wider section of society in their construction. Verbong and Geels (2007) characterise regimes as containing: (a) a network of actors, (b) formal, normative and cognitive rules, and (c) both material and technical elements. In this model the regime is remarkably similar in 
definition to the whole socio-technical system, reflecting the important place they occupy in the MLP. Landscapes are macro-level movements and concern phenomena that work on a wider scale. Macroeconomics and symptoms of modern society like consumerism or individualism all operate on a landscape level. Of course, all three levels do not operate in a vacuum and influence each other. Of interest to us here is that, according to the MLP, a transition is described as a shift from one regime to another (Geels and Schot 2007, p. 399).

Seeing communities as niches-, or niche-innovations, then involves seeing them in the nested hierarchy, at the bottom scale. However much they are novel and innovative, they are contained within this hierarchy. Although Seyfang et al. (2010, p. 8) suggest that the MLP is not necessarily hierarchical, situating this hierarchical view within the "managerialist transition management literature". There is, Seyfang claims, much in common between social practice theory and the "original conceptions of the MLP" (2010).

The assumption throughout community as niche and social innovation (Section 2.3), is still that transition occurs when niches emerge and "become sufficiently powerful to challenge and, ultimately, overthrow dominant systems" i.e. the regime (Seyfang et al. 2010, p. 3). Yet, by assuming that such niches are defined in opposition to the regime, they are conditioned by and embody the regime as much as if they had modelled themselves on it. This conception also comes with normative assumptions as to what constitutes "success" for such niches. Success is seen here as a growing in scale, challenging directly the existing regime and seeking to take their place in the mainstream. Niches that alternatively seek to ignore or undermine, rather than challenge the existing regime practices are not represented in this view of community. The participants of Carbon Conversations or Transition Towns (Sections 3.1 and 3.2) were often there due to a desire to reject such normative expectations. Also, niches that retain no desire to be successful in conventional ways, or have a sustained existence are not accounted for either. TAZ-like ${ }^{2}$ (Bey 1991), amorphous, spontaneous, emergent communities would not fit this typology, for example Occupy. Transition Towns initially desired to "die" as an organisation - the first of the initial 12 steps had "sow the seeds of the groups' demise from the outset" - partly in order to seed off future initiatives (Hopkins 2008). Those in community initiatives can feel frustrated when mainstreaming occurs. AGMs, constitutions, office bearers, and bank accounts are necessary upon reaching a certain size. They can also prove offputting; indicators of growing into the mainstream are often outright rejected by many volunteers who constitute niche communities.

In this conception, "community" here is a collective, progressive mobilising force. It is a willingness to step outside of existing relationships and orderings of life; but only so far as they then step back into the mainstream. Seeing "community" initiatives as niche-innovations involves seeing them as strategic, tactical entities, with a desire to grow in level or size (up-scale), and take their place in the mainstream. This view though removes much agency from the "community" initiatives, by talking of "path dependency" (Berkhout 2002) and "lock-in" (Unruh 2002, Foxon and Pearson 2008). The "community" is thus structured by landscape and regime forces, and only exists towards impacting it. Viewing "community" initiatives purely as niches can rob them of their social and spatial particularity. Issues of space and place seem not relevant for niches, or are at least no more than incidental factors. Community groups, certainly bottom-up community groups, can emerge in specific contexts to serve specific needs, and when those needs are met or alter, such community groups can fragment, morph or even disappear. By seeing "community" as devoid of context, it does violence to the singularity of community initiatives. Seeing "community", or community projects, purely as a niche or niche-innovation is then incomplete and geographically naïve. 


\section{3. “Community” as a social innovation}

Most problematic with the literature on niche-innovations, when looking at "community", is the overly technological outlook. As a reaction to this, a friendly critique has emerged of this use of niches, describing them as social innovations. Social innovations are "new forms of socio-economic organisation" (Schreuer 2010, p. 101) who are "operating in a field where they are dependent on the available technologies and on institutional framework conditions, but at the same time also actively shaping these environments to some extent through their own activities" (2010, p. 105). "Social innovations" is partly an attempt to move away from technologically focused categories, as niches can be seen, where the roll-out or adoption of the niche is part of a curve, targeting individual rational actors (Seyfang 2009, p. 69);or indeed moving away from seeing the "mainstream" or "regime" as a coherent, stable system. Social innovations on the other hand, are like "community energy" projects in the UK (Walker 2008), or locally owned wind turbines in Denmark (Toke et al. 2008).

Scott-Cato and Hillier (2010, p. 870) define social innovation as "refer[ing] to academic and other intellectual activity that actively engages with contemporary social problems to achieve socially beneficial outcomes". For Seyfang (2009) also the focus is shifted to a particular situation, with locally specific needs, capabilities and awareness. These innovations are social as they shift the focus from end user, to a locally specific context where new forms of energy production and distribution, can be experimented with - alongside the social arrangements that make this possible. It is this experimenting with existing technology, in tweaked social settings, that alters the relationship between the infrastructure, practices, and habits (Shove 2003). Social innovations then are not technologically focused, yet they do make use of emerging and existing technologies. They are concerned about reframing social habits and practices as much as about placing themselves as the "early adopters" of new technological innovations.

This is highly relevant for any study of community-based approaches to (un)environmental behaviours and practices. However, seeing these "community" initiatives as a social innovation only goes so far. In not recognising and including space, place, scale or environment, characterising "community" as a niche in the MLP faces the charge of not being rigorous enough. Social innovations readdress one of these: scale (although an argument can be made for environment, as context). Social innovation is primarily a scalar category; they are small-scale and local in terms of both size and level. One can describe groups such as Transition Towns as social innovations, and to a certain extent this label can cover all community groups, energy cooperatives, and grassroots emergent examples, if not top-down imposed communities. However "community" groups need spatial analysis due to "community's" amorphous, phatic nature - its polysemic use.

When working with the Transition Town groups, members of the initiative were explicitly encouraged to introduce themselves as being part of a "community project" when talking to "outsiders". It is interesting to consider whether members introducing themselves as members of a "social innovation" would have the same effect. The point to be gleaned here is that to identify oneself as belonging to a "community" has specific and desirable connotations not held by alternative labels. Theoretically too, "community" has a legacy of traditional, warm feeling, and being a safe concept (Bauman 2001, Delanty 2010). This is part of why we should resist understanding these projects solely in terms of "social innovation". These are geographic reasons: questions of place, belonging and spatial imaginings are just as crucial in providing a comprehensive account of "community" as environment and scale. 


\section{4. “Community” as a grassroots initiative}

Another way to characterise the community response to environmental challenges is as grassroots initiatives. Grassroots innovations emerged from the literature on niches in the MLP, influenced by STS. For Seyfang, grassroots initiatives are "networks of activists and organisations generating novel bottom-up solutions for sustainable development and sustainable consumption; solutions that respond to the local situation and the interests and values of the communities involved" $(2009$, p. 64). There is the sense here of grassroots organisations coming up from below, emerging from the shadows to take their place in civil society. Rather than waiting for the mainstream to come round to green ideas.

Seeing grassroots innovations as "communities" has a long lineage. For Smith (2005) the current focus on renewable energy has roots in the alternative technology movement of the 1970s. Smith invites us to remember the radical edge this movement had, and even though this route was not taken, it had recurring impacts. Not least that current members of business involved in greenwashing often had schooling in this alternative technology movement. Yet the description of these "communities" as "grassroots innovations" is contradictory. Defined as being against the mainstream they still "hold normative promise" (Seyfang and Smith 2007, p. 595). As seen with the previous two ways of understanding community influenced by the MLP, they are at once defined as against the mainstream, yet drawn irresistibly towards impacting upon it.

So with grassroots initiatives, there is more spatial analysis, more of a sense of each example of singularity and particularity. Yet, there is still the normative promise that they will grow to impact the mainstream. However, with many grassroots examples, it can seem far-fetched to see them aim for this level of mainstream impact. Groups would have two options here. First, they form communities of communities. Here umbrella groups may shelter emerging communities and help them to feel part of a progressive coalition. For example the Transition Network can be understood as fulfilling this role, for its constituent Transition ${ }^{3}$ cells. Alternatively they themselves may have impact, but not directly, at least not tangibly. They could have symbolic value, leaving behind an inspirational story, or example of how someone did something differently. Transition groups, for instance, can draw inspiration from forebears such as Levelers or Luddites.

"Community" here is characterised by "small-scale local activity". To see community as a grassroots innovation is primarily, if not purely, to see it as a scalar category. Community here is also a place, a local place, where things are done differently to an "out there" mainstream. Again, defining themselves against a mainstream means embodying it despite not setting out to copy it directly. Yet, grassroots innovations have concern for the local particularity of each emerging "community" initiative.

\section{5. “Community" as a context for behaviour change}

Moving away from the dominance of STS and the MLP, there are various other ways of understanding these "community" experiments or interventions. These feature with both policy-makers (CSE 2007, IPPR 2010, RSA 2010) and academics (Jackson 2005, Middlemiss 2009). Within these lies a trend emerging where the attempt is to affect individual behaviour change, albeit through the medium of "community".

This recent spate of literature posits the untapped potential of "community" to help encourage pro-environmental behaviours and practices. "Community" here is envisioned as a support network, with members encouraging each other collectively to help reduce the community's environmental impact, in aggregate. The individuals who make up this 
"community" have common aims and values. This is centred on the long-standing assumption of "community" as partly homogenous (Crow and Allen 1994, Delanty 2010), with normative assumptions of what "being in" the community means. Some initiatives, such as a Carbon Conversations course, seek to develop explicitly pro-environmental assumptions as to what being in the "community" means. For Carbon Conversations, the participants choose to "opt-in" to a course designed to reduce their carbon footprint. They stay in, with the sole aim of weaning themselves off their perceived addiction to oil. This is the uniting factor that holds the community together.

The normative assumption or homogeneity does not have to be an environmental one. Baldwin (2010a) discusses an initiative at Ipswich Town football club where supporters were encouraged to, "Sav[e their] energy for the Blues". This tapped into the supporter's common desire to see Ipswich succeed and sought to win money for their team for new players. The aim was to see the club achieve the oft-lauded goal of being "carbon neutral" (Baldwin 2010b). Supporters did this by, again, adopting individual behaviour change pledges, motivated by the thought that their self-sacrifice was doing some greater good for the whole.

Jackson (2009, p. 150) has talked about the untapped potential for communities to be used as a vehicle for low carbon lifestyles: "Individual efforts to live more simply are more likely to succeed in a supportive community", giving examples such as the Findhorn Foundation, where the aim is declared to be as empty and profound as "living simpler, more sustainable lives" (2009). Typically, the construction of this kind of "community" relies on normative assumptions and the homogenous nature of the shared goal.

Viewing "community" as the best way to reduce environmental emissions is in part a reaction to purely individual ways. This view offers a critique of the belief that information and advice on "virtuous" ways to live - "correct conduct" for Foucaldians - are enough to motivate individuals' change in practice (for instance, Hinchliffe 1996). Yet, it is worth asking if "community" as a reaction to this individual outlook does not move far enough away. It alters the context of the individual behaviour change, but is still focused on individuals changing their behaviour. Seeing individual behaviour change in a group context is not very different from a "community" one and it is unclear what is gained by the use of the term "community". We must also account for the non-human and more-than-human elements that make up certain communities, left to one side in this reading of community. A less individualistic approach might take into account the technologies, infrastructures, sense of place, spirituality, memories and biographies, and other crucial more phenomenological aspects of community, to name just a few. These all impact - subtly or otherwise - on the community feel and are neglected.

Community is, as with any other term, never neutral. It is used widely to encompass a variety of meanings, feelings and values. Whether consciously or unconsciously, it is used with the duel entity of signifying both "location and its value-laden entity" (Fremeaux 2005, p. 268). Conceiving of behaviour change as primarily individual-centred neglects the extent to which other factors bear on this process. In particular it decontextualises and abstracts behaviour change from the context in which it takes place and of which it is motivated by. The belief for those seeing "community" as a supporting context for individual behaviour change implies "community" is that which aids our ability to be virtuous. Community here has a warm, positive function that implies that it is something worth working for: community predicates assumed virtue. Previous analysis of New Labour's use of the term "community" points to its moralising nature (Wallace 2010), and its willingness to delegate responsibility away from governments and corporations, to those as seen as inside community - for instance in Etzioni (1993) and Fremeaux (2005). If "community" understood as a 
niche can be seen as having too little agency, "community" as a context can ascribe more agency that is reasonable to groups. As Shove (2003) points out, behaviours and practices and the capacity to change relies on norms and technologies beyond virtue, willingness or capacity to change,regardless of the supportive context we place (or find) ourselves in.

Seeing "community" as a context for individual behaviour change does provide a more subtle look at its locational links. Community is here linked to place, but not tied to a bound territory. By focusing on the normative, and virtuous aspects of the terms here though, there is a danger of heading towards seeing "community" as a panacea. It is important to point out here then, that although "community" is seen less abstractly here, we should not mistake that for being seen as neutral. There is less in these analyses of "community's" powerful forces of normatively held assumptions and beliefs, and of homogeneity within the group, that can be used for potentially reactive, regressive means as much as the progressive ones the authors above talk of.

\section{6. “Community” as a TSO}

Third sector organisations (TSO) are also known as the volunteer sector, and can be termed the not-for-profit, or more-than-profit sector. The rise of the term TSO was linked to New Labour and its focus on "community" (Levitas 2000, Raco and Flint 2001, Flint 2003). In this way, "community" and TSO's have, to some extent, a shared heritage: as the "third way" between the public and private realms.

Within the literatures on transition, there is a growing appreciation of the impact that community groups can have. Middlemiss (2009, p. 8) explores the role of communitybased groups in affecting a change in behaviour and social practice. Outlining the potential reasons for community groups success at this, Büchs et al. (2011) talk of the proximity of TSO's to citizens, and the greater trust that citizens have in TSO's rather than government or business. However, seeing community initiatives in the transition to low carbon futures as TSO's only recognises those communities who are coherent, constituted groups. It neglects the "communities" that are operated on, in favour of those "communities" that are doing the operating. To see "community" as a TSO, would be to see the "community" involved in the transition, as the volunteers, paid employees, etc., rather than those who are "targeted" as the ones needing to transition.

Of relevance when looking at "communities" transition to low carbon futures, Büchs et al. (2011), building on Mouzelis (2008) identifies two different "sources" of practice change: actor-related and context-related. Actor-related change refers to the meanings, agency and beliefs of individuals. Context-related refers to the structures, infrastructures, and (natural) environments. Although these two are difficult to distinguish in empirical examples, it provides a useful heuristic.

Where can we place "community" initiatives in this typology? Some - for example Carbon Conversations - explicitly talk about using community group norms to affect individual behaviour change. In this sense community is being used to change actor-related environmental behaviours. However there are others, such as Transition Towns, where the attempt is to alter the whole fabric of the community - the place, the town towards sustainable living. This envisioning of wholesale change and the reconfiguring of habits, practices and infrastructures concerns context-related change.

Both practice and context related changes can be seen in the patterns of use of community in the attempted transition of both Carbon Conversations and Transition Towns. Once again we find that the term "community" is used in a rich and varied way referring both to actor- and context-related changes. This is perhaps community's advantage and reinforces 
the point that community can and has been seen in a wide variety of contexts. TSO's, as other framings, can go far beyond purely local attempts to affect change. The question then emerges as to why government views such as the CCF would neglect these in preference for its own preferred vision of "community".

\subsection{Community synonyms}

Each of these different schools of literature has a different way to mobilise or envisage the concept of "community". There are some similarities, for example, the link between smallscale and community exists to some extent in all the examples seen here. Differences exist though, and these might be best seen in the attempt to find the most suitable synonym for each example. The niche is seen as in the early stages of development. "Community" here is fragile, embryonic and filled with potential. As a social innovation, "communities" are novel, experimenting, vanguard. For grassroots innovations, "community" is primarily a scalar category. An apt synonym here could well be "local". "Community" as a context for individual behaviour change primarily looks to the potential for an echo chamber of homogeneous people to feed off each other's ideas, keeping in check and pushing people to beliefs and behaviours they would not reach alone. "Community" here can be seen as an ego-corrective or even cultish. Finally, to see "community" as a TSO involves seeing it as the prime mover or agent of change, rather than the thing that alters itself.

As we have seen, there are a variety of ways in which "community" can be understood as a response to the global environmental challenge. Yet government initiatives, such as the $\mathrm{CCF}$, tend to associate "community" with a location based definition, eliding it with the local (Amin 2005, Fremeaux 2005). This helps explain the CCF heavily funding both Transition Towns and Carbon Conversations. It is this sense or association that community carries with it in policy and government circles that is problematic. It is to these governmental associations and two empirical examples of them that this paper now turns.

\section{Government by (local-) community}

Governments are increasingly using community as a medium and site of response to the challenge of climate change. The community referred to is often inflected towards a silently implied prefix local: the (local) community (Walker 2011, Bulkeley and Fuller 2012).

The idea of "government by community" (Raco and Imrie 2000), or "government through community" (Rose 1996) is not new. However, in environmental governance, community is increasingly being used to govern environmental behaviours and practices. This emerges against the backdrop of an increasing neoliberalisation of the State (Jessop 2002, Harvey 2005). Government through "community" here is based heavily on Foucault's notion of "governmentality" (for instance, Foucault 2007 [1978]).

At the heart of governmentality it is understood that liberty and security, or consensus and coercion, are not binary opposites but can rather reinforce and balance each other (Aiken 2012b, p. 25). For "community" to be adopted as a form of governmentality means a state's governing is not through an encroaching of individual liberties, which neoliberalism abhors, but through a manufactured consent. "Community" here is used in order to help internalise that consent. In this way "community" is a technology of government.

The type of "community" envisioned here is firmly place-based. As Amin (2005) points out, when "community" is used it is often elided with a silently implied prefix of local. This is government through (local-)community. It is also elided with place, and (small) scale, but local is focused on here. Governing by community also implies the notion of governing at a 
distance; rather than directly regulating, states govern at "arm's length". In states characterised by dispersed networks - rather than nodes - of power, and the prominence of "freedom of choice" for its citizens, such a form of govenmentality is required to negotiate the environmental challenge faced. It is here that this primarily place-based (local-) community enters. This is the case for governance more generally, and similarly for UK environmental governance. UK government reports, either directly funded or tacitly encouraged in think-tanks, have proliferated, extolling the virtues of a "community" response to the environmental challenge. From the Green New Deal to RESOLVE's Community Action report (2008), community is a core theme in the attempt to govern the transition to low carbon futures.

The "Green Streets, Strong Communities" report (IPPR 2011) posited an iterative beneficial relationship whereby "stronger communities" automatically meant a greener one. Similarly, the more green an individual, group or society was, the greater the feeling and bonds of community. Community here is both a normative good and a direct correlative of "green" (cf. IPPR 2010). In this report the barriers to community are the very same barriers to greening the UK's streets (attitudes and beliefs, planning system, financing of such projects). The key conclusion is that "community-led engagement is particularly effective" (IPPR 2011, p. 42). In an age of austerity, community projects offer perceived value for money: effectiveness. This helps explain their increased uptake by UK governments. The "Connected Communities" (RSA 2010) report on likewise posits the normative good and efficacy of (local) community and its natural link to pro-environmental behaviours.

The type of "community" envisioned in these reports is again firmly local. Community when invoked is either elided with, or used as a synonym for, the local. The name of the Centre for Sustainable Energy project "Planning for a Low Carbon Living" says it all: PlanLoCaL. Described as "Giving communities the knowledge and confidence to influence local planning policy and contribute to a low carbon future", ${ }^{4}$ PlanLoCaL assumed that "communities" are inherently place-based and small-scale enough to be described as local. That this was funded by the then "Department for Communities and Local Government" reinforces the government support for such rhetoric and elision.

This demonstrates the prevalence and rise of "community" in environmental governance "at-a-distance" in the UK. The focus on (local) "community" can also be seen in the CCF: the Scottish Government's cornerstone attempt to reduce carbon $(42 \%$ by $2020,80 \%$ by 2050 on 1990 levels). ${ }^{5}$ In 2008 , the SNP, supported by the Green Party established the $\mathrm{CCF}$ - reduction of deleterious climate change generating emissions being explicitly through the medium of community. There were only three criteria for funding applicants: the "community should be at the heart of the decision making process"; the project "should lead to significant $\mathrm{CO} 2$ reductions"; and "it should result in a positive legacy for your community". 6 Though community was central it was not tightly defined. This is typical of the use of community gesturing towards some positive well-meant sense of locality, rather than anything firmly denoted. Community's meaning here was as via negativa, a means to exclude NGOs and local authorities. Yet it was in and through "community" that the carbon reduction targets were to be achieved.

A government commissioned study reviewing the first three years of the CCF concluded: "that community projects are well-placed to deliver pro-environmental behaviour change" (Scottish Government 2011, p. 8). This was due to three reasons: their "ability to tailor and personalise their messages and interventions to appeal to individual participants' motivations"; "Their position in the community as trusted entities that are seen to have the community's interest at heart"; and "their ability to engage those who are "moderately interested' in the environment and open to the idea of change, and spark them 
into action". There are several interesting aspects to this conclusion. As is typical, the word "community" is used three times, to three apparently different ends (project, location, group). Regularly, as Warren and Birnie (2009) conclude, the appearance community gives, rather than its specific denotations, is the important aspect of its use in environmental governance.

Seen through the lens of Foucault's governmentality however, it is noticeable that the Scottish Government, through CCF, seeks to govern the environmental behaviours of its citizens, by appealing to "individual motivations", gaining widespread consent across major sectors of the population, not just a minority interest group of "usual suspects" who would take environmental action. Given the polysemy and theoretical multiplicity of community seen in Section 2, and the governmentalising and narrowing of community in the CCF, how does this look on the ground? Two prominent examples are explored below, both showing the CCF desire for "local" community. One - Transition Towns - local in terms of place, the other - Carbon Conversations - local in terms of scale, in this case small-scale.

This research was a three-year study of the UK government's use of community in the transition to low carbon futures. It comprised ethnography with different groups, including, of relevance here, three TTN groups and one Carbon Conversations course. Alongside this participation, participants from the course were interviewed before, during and afterwards. These were transcribed, coded and analysed. TTN volunteers and staff workers, CCF funding panel members, external consultants, former group members, and relevant local actors including councilors were also interviewed. In total 47 semi-structured interviews and three focus groups feed into this empirical data. Such a wealth of empirical data are briefly outlined next. Pervading all this diverse array of actors, the assumption was that community is necessary for global challenges, of transition to low carbon futures, and that the governmentalised community, is a local community.

\subsection{Carbon conversations}

Carbon Conversations is a 6-session course developed by Cambridge Carbon Footprint, and now operated by Climate Outreach and Information Network. It is designed to encourage discussion and engagement in low-carbon living. During six 2-hour sessions the facilitators lead the course participants through the Carbon Conversations handbook, a colourful and glossy information-packed guide to the six separate topics. ${ }^{7}$ It is notable for its focus on the emotional aspects of climate change, although Carbon Conversations relies on plenty of statistics and facts concerning carbon emissions (Hargreaves 2012).

Rosemary (Ro) Randall conceived and developed Carbon Conversations (2009a), whose psychotherapist background inevitably impacts the course. She describes them as: "small support groups, whose goal is to achieve major, personal carbon reduction" (2009b, p. 118). The psychological nature of its genesis impact on the way Carbon Conversations go about attempting this reduction. They "deliberately set out to address the emotional impact of the changes we need to make and provide structures for sharing feelings and working through resistances and difficulties in personal carbon reduction" (2009b, p. 126). Randall contrasts this to other groups of people coming together to act on environmental issues, such as car-share schemes or low-energy clubs. These, she argues, are characterised by a "pioneering spirit", a can-do, vanguard approach that finds it hard to accept less positive emotions being mentioned. Carbon Conversations is differently designed to facilitate a space where its participants can normalise "the sharing of difficulty, disappointment, frustration and loss" (2009b) involved in altering one's practices, attitudes and opinions. 
The "community" aspect of these groups is in participants going through a collective experience, delving into different aspects of their lifestyle and practices. It is through this collective enquiry that participants ask deeper and more challenging questions about themselves. It is legitimate to speculate on just how community-based these groups are, focusing as they do on individual change, albeit in a group context. The focus remains on a personal carbon reduction, akin to community as a context for individual behaviour change (Section 2.5). Part of this is due to the nature of the groups: the temporary nature of 6,2-hour sessions does not provide the context for community belonging, as traditionally conceived. However the groups reach a depth that would not otherwise happen if individuals were reading the booklet and doing the reflection activities alone. Many of the group activities, such as the splitting into $2 \mathrm{~s}$ and $3 \mathrm{~s}$ and the discussions, create a feeling that there are others who are going through the same struggles. In this sense it removes the feeling of acting alone, or the "helplessness" (Heiskanen et al. 2010 , p. 7588 ) that has been identified as a major asset to the "community" approach to transition. It also may be the case that the temporary nature of these groups enables a depth of critique to one's own practices that would not otherwise be possible with more permanent relationships.

One of Carbon Conversation's key themes is that it helps participants to open up to the loss and pain that the transforming of one's practice can entail. It asks difficult questions, and goes where other groups may shy away. Intriguingly, one of these other groups is the Transition Town model (next section), seen as a "more romantic version of a preferable future" (Randall 2009b, p. 120). A key aspect for Carbon Conversations is the difference between intrinsic and extrinsic motivations for action (as developed by Crompton 2008). Carbon Conversations prefers to focus on intrinsic, internal motivations for action. For example the first session talked about one's "beliefs" about climate change. Throughout the course there are personal stories, from "real-life" individuals with pictures and speech bubbles in the course handbook. This helps to create a connection to those others who are also going through the same thoughts and feelings. The speech bubbles emphasised the subjective feelings of environmental concerns by focusing on various members of religious groups whose ethics concern care for the environment. It also strongly suggests that one's opinion on environmental concerns was a position of faith. Science and facts were involved in the discussion/handbook, but only loosely guiding it, if at all. This also played out in the group I participated in. Both a "self-proclaimed Christian" and "scientific atheist" stated how beliefs led them to want to act on environmental issues. That two divergent views could be brought to the fore on only the first session could indicate that these were flippantly held. However I suspect that this was more down to the welcoming temporary space created, making opening up possible. This set the tone for future sessions where some reasonably deep personal issues were shared. Most of the actual discussions were carried out during the weekly evening meetings, although the engagement continues throughout the week as well. There were regular e-mails sent out to remind the group of previous, and upcoming topics of discussion, and links to relevant youtube clips and online articles that took the issues further. These were often "replied to all" the group, creating a flatter hierarchy of information sharing and discussion.

A participant felt Carbon Conversations to be similar to to the "weight watchers" model, united by a common interest, and mutually supporting and encouraging one another in their attempts to lead a more environmentally sound lifestyle. There was also sharing of what some participants found difficult and collective empathy for difficult situations and tensions, in regards to Carbon Conversations aims, for example families abroad that required flights if visits for Christmas were to be made. 


\subsection{Transition towns}

The Transition Town movement has achieved greater prominence, in terms of both numbers involved and its impact on the popular press (Hickman 2009, Irvine 2009). Crucial for this organisation is their explicit focus upon "community". The Transition movement continually refers to itself as a "community-led" calised community" (Hopkins 2008, 2011). "Community" is used here open-endedly, polysemic if not multivalent. However, it also refers to the proleptically inaugurated vision of the future they wish to see - that of the resilient relocalised community.

Some have seen Transition as a test-case for integrating different philosophies and schools of thought into this "community" movement: Deleuzean (Scott-Cato and Hillier 2010), permaculture (Aiken 2012a), or ethical place-making (Mason and Whitehead 2012). Despite this diversity of approaches to analysing the significance of Transition, constant to these is the "community" dimension identified in the movement. Constant too, despite its widespread application, is what "community" refers to. It is elided with the "local", most noticeably in the sense of community of place. "Community" is process, the action needed to get to their destination: "If we wait for governments, it'll be too little too late. If we act as individuals it'll be too little. If we act as communities, it'll be just enough, just in time". 9 Yet "community" is also the destination, their imagined future and telos, characterised by "local resilience" (Hopkins 2008). That this "community" refers to a local place, can be seen in the names for each Transition initiative, often referring to a local place, be it town, neighbourhood or region as, respectively, Transition Town Totnes, Transition Brixton, Transition North Howe.

\subsection{Community implies "local"}

In both CCF-funded examples here, "community", identified as a key response to global environmental challenge, is elided with the local. Local can refer to scale, as in Carbon Conversations, or local as place, as in the Transition Town model. Yet the notion of "community" referring to local is implicit throughout the CCF. This artificial limiting of "community" was not inevitable though, and there remains a wide array of potential deployments and understandings of government use of "community" in the transition to low carbon futures.

\section{Critiquing (local-) community-beyond-the-state}

Beginning with "State-based arrangements are hierarchical and top-down (command-andcontrol) forms of setting rules and exercising power", Swyngedouw (2005, p. 1994) then heralds the arrival of "governance-beyond-the-state systems, in contrast, [which] are presumably horizontal, networked and based on interactive relations between independent and interdependent actors who share a high degree of trust, despite internal conflict and oppositional agendas, within inclusive participatory institutional or organisational associations". Government turns into governance in governance-beyond-the-state, Swyngedouw's encompassing term for "government by community" (Raco and Imrie 2000) or "government through community" (Rose 1996). Yet, "beyond" supposes that a separation can be distinguished where the state, stateness, state effects and state governance can be seen to begin or stop. Following Painter's (2006) conception of the "prosaic state", the border of state effects of the institutional or centralised edifice of the state is impossible to locate, if indeed it exists. Rather the line between civil society and state cannot be 
drawn or identified. Thus, governance-beyond-the-state assumes too narrow conception of state, and that governance would be different beyond such state boundaries. This research on the state-funded expressions of community such as certain Transition Towns, or Carbon Conversations, shows that state effects reach beyond the institutional state, into the prosaic, everyday, banal and quotidian: into community. The environmental governance technology or governing technique used to effect this in Scotland was the CCF (Stewart et al. 2013).

Swyngedouw ties the participative/participation agenda to governance-beyond-the-state, and the shift from government to governance. In this subjects and citizens are not governed to but governed with. Thus is includes an increasing legitimisation and co-implication of citizens with government actions and decisions. At the very least responsibility is shared between citizens and governments, this research demonstrating that responsibility is delegated to or projected upon individuals, communities and grassroots actors, away from established state actors. These are "socially innovative practices in urban governance and territorial development invariably associated with the emergence of new institutional forms that draw heavily on a greater involvement of individuals or actors from both the economy and civil society" (Swyngedouw 2005, p. 1992).

Can such a binary claim stand up? Particularly after Elden's (2007) argument against Foucaldians identifying a linear and simple division between government and governance. This is a fruitful - certainly successful and popular - heuristic used to understand state governance in individuals, communities and grassroots lives, but adopting it as a trope, unquestioningly, is problematic when missing the subtleties involved in state influence in individuals lives.

The binary can be very useful in drawing our attention to the coercive use of seemingly consensus-based politics (Janus-faced), but it is not that coercion only comes into play after government is replaced by governance, and hierarchy by horizontal networked society. Both open up opportunities for some the other denied (e.g. Transition Towns in the new model of governance), and neither are purely removed from the other. As Painter argues the state can be found in both top-down directive planning, and inclusive partnerships and inclusive agendas (so called governance-beyond-the-state). Governance as governance-beyond-the-state, turns out to be state governance all the same, albeit at a smallscale, grassroots and local level.

Here is the relevance for the use of community in environmental governance. Community in the examples above is not a site removed or free from state power and state effects, but is a key site where the state can be seen to act; in this case through the local elisions of community, and the delegation of responsibility and (rhetoric of) agency to individuals for their carbon lives. Thus in the research presented here we see the role "community" plays in continuing a state governance beyond the tradition or established state. State effects at a community scale, through the CCF-funded Carbon Conversations and Transition Towns.

\section{Conclusion}

The governmentalisation of community and its elision with local invoke Waldo Tobler's first law of geography: "Everything is related to everything else, but near things are more related than distant things" (Goodchild 2009). Yet such assumptions of spatial autocorrelation and that solutions to global challenges must involve local communities says nothing about causality, or the performative implications of government presumptions of community as local, heavily funding such schemes, thus empirically (re)producing (local-) community on the ground. 
The point here is not to posit some new, or overlooked understanding of "community", but to draw attention to the multiplicity of interpretations, mobilisations and deployments of "community". With this understanding, the increasing state reliance and governmentalising of "community" - with its silently implied elision of local - begins to look more suspect. Community as local is preferable to, and more easily instrumentalised for states seeking to govern individuals' carbon lives.

This is a highly selective story, only addressing two of the many projects funded by the CCF. However, it outlines some of the potential traits that the notion of "community", its fusing with the local, yet also its central relevance in combating global issues like climate change has. This begins to look like a Gramscian or neo-Gramscian analysis, where the hegemony, the thoughts, or the way we think about "community" impacts on the ground, through government funding schemes, and think-tank influenced opinions. The current or vogue perceptions of "community" affect which projects "fly" and which do not.

This paper focuses on the governmentalisation of community at the local level. Postpolitical writings can often assume that community and environmental issues are rendered uncontentious, pacifying dissent through a smothering blanket of phatic belonging (as "community" is often used). More nuanced, this argument draws attention to the ways in which community emerges as a site in response to global challenges. Yet, this response is still governmentalised in tone, resulting in the localisation, and firm elision between local and community required to delegate agency and responsibility for global events onto individuals on the ground. The paper thus draws attention to the ways in which community has been localised when used as an extension of the "prosaic state", in an attempt to govern environmental behaviours in the UK today.

\section{Acknowledgements}

I must thank a number of people for looking over and providing advice on improving the text, and for discussing the ideas explored here: Harriet Bulkeley, Sara Fuller, Joe Painter, Anna Schreuer, and Amanda Taylor Aiken; and for Stewart Barr, Patrick Devine-Wright and Joseph Murphy, at whose session at the RGS-IBG this paper was presented, for your encouragement to develop these ideas into a publication. Both reviewers were helpful and encouraging in different ways. Thank you. The responsibility for the faults and arguments here, of course, remains my own. The $\mathrm{PhD}$ research upon which this article was based was conducted as part of the ESRC Climate Change Fellowship, "Urban Transitions: climate change, global cities and the transformation of socio-technical networks" (Award Number: RES-066-27-0002), led by Harriet Bulkeley.

\section{Notes}

1. "Words have meanings. Some words, however, also have a feel" (Bauman 2001, p. 1).

2. Not necessarily the Temporary Autonomous Zone's Bey describes, but any group with a desire to have a temporary existence.

3. Transition with a capital, as a noun, refers to the Transition Town Movement. Not to be confused with transition as a verb and theoretical concept.

4. Available from: http://www.planlocal.org.uk [Accessed 17 November 2013].

5. Climate Change (Scotland) Bill (Ex) (E), Received Royal Assent, 4 August 2009.

6. CCF website: http://ccf.keepscotlandbeautiful.org/ [Accessed 17 November 2013].

7. These six topics are: "looking for a low-carbon future", "energy in the home", "travel and transport", "food and water", "consumption and waste", and "moving on".

8. Available from: http://www.transitionnetwork.org/ [Accessed 17 November 2013].

9. Available from: http://www.transitionnetwork.org/support/what-transition-initiative [Accessed 17 November 2013]. 


\section{References}

Aiken, G., 2012a. Community transitions to low carbon futures in the transition town network (TTN). Geography Compass, 6 (2), 89-99.

Aiken, G., 2012b. UK environmental governance through community. UGEC Viewpoints, 7 (May), $24-27$.

Amin, A., 2005. Local community on trial. Economy and Society, 34 (4), 612-633.

Baldwin, R., 2010a. Football and climate change: strange bedfellows or a means of going beyond the usual suspects in encouraging pro-environmental behavioural change? Local Environment, 15 (9-10), 851-866.

Baldwin, R., 2010b. Can (A Football) community Tackle climate change?: acase study analysis of Ipswich town football club's campaign to encourage pro-environmental behavioural change amongst its fans. CSERGE Working Paper EDM 10-05. Available from: https://ueaeprints. uea.ac.uk/20227/ [Accessed 17 November 2013].

Bauman, Z., 2001. Community: seeking safety in a world of insecurity. London: Polity.

Beck, U., 2006. Cosmopolitan vision. Cambridge: Polity Press.

Berkhout, F., 2002. Technological regimes, path dependency and the environment. Global Environmental Change, Part A: Human and Policy Dimensions, 12 (1), 1-4.

Bey, H., 1991. T.A.Z.: the temporary autonomous zone, ontological anarchy, poetic terrorismautonomedia. Available from: http://www.hermetic.com/bey/taz_cont.html [Accessed 1 November 2013].

Büchs, M., Smith, G., and Edwards, R., 2011. Low carbon practices: conceptualising the role of third sector organisations in promoting change. TSRC working paper mb 6 Dec 01/02/2011. Available from: http://www.cultureworks.info/downloads/lowcarbon_practices_a third_sector_research agenda.pdf [Accessed 17 November 2013].

Bulkeley, H. and Fuller, S., 2012. Low carbon communities and social justice. Viewpoint for Joseph Rowntree Foundation Available from: http://www.jrf.org.uk/sites/files/jrf/low-carbon-communitiessummary.pdf [Accessed 1 October 2013].

Centre for Sustainable Energy (CSE), 2007. Mobilising individual behaviour change through community initiatives: lessons for tackling climate change. Available from: www.cse.org.uk/pdf/ pub1084.pdf [Accessed 17 November 2013].

Crompton, T., 2008. Weathercocks and signposts - strategies for change. WWF.

Crow, G. and Allen, G., 1994. Community life. London: Harvester Wheatsheaf.

Delanty, G., 2010. Community. London: Routledge.

Elden, S., 2007. Rethinking governmentality. Political Geography, 26 (1), 29-33.

Etzioni, A., 1993. The spirit of community. Rights, responsibilities and the communitarian agenda. New York: Crowns.

Featherstone, D., 2013. The contested politics of climate change and the crisis of neo-liberalism. ACME: An International E-Journal for Critical Geographies, 12 (1), 44-64.

Flint, J., 2003. Housing and ethnopolitics: constructing identities of active consumption and responsible community. Economy and Society, 32 (3), 611-629.

Foucault, M., 2007 [1978]. Security, territory, population. Basingstoke: Palgrave Macmillan.

Foxon, T. and Pearson, P., 2008. Overcoming barriers to innovation and diffusion of cleaner technologies: some features of a sustainable innovations policy regime. Journal of Cleaner Production, 16 (1) S148-S161.

Fremeaux, I., 2005. New labour's appropriation of the concept of community: a critique. Community Development Journal, 40 (3), 265-274.

Geels, F.W. and Schot, J.W., 2007. Typology of sociotechnical transition pathways. Research Policy, 36 (3), 399-417.

Goodchild, M.F., 2009. First law of geography. International encyclopaedia of human geography, Amsterdam: Elsevier.

Hargreaves, T., 2012. Carbon conversations: an innovation history [online]. CISE. Available from: http://www.grassrootsinnovations.org [Accessed 17 November 2013].

Harvey, D., 2005. A brief history of neoliberalism. Oxford: OUP.

Heiskanen, E., Johnson, M., Robinson, S., Vadovics, E., and Saastamoinen, M., 2010. Low-carbon communities as a context for individual behavioural change. Energy Policy, 38 (12), special section: carbon reduction at community scale, $7586-7595$.

Hickman, L., 2009. What next for Transition Towns? The Guardian, 28 May. 
Hinchliffe, S., 1996. Helping the earth begins at home: social constructions of socio-environmental responsibility. Global Environmental Change: Human and Policy Dimensions, 6 (1), 53-62.

Hopkins, R., 2008. The transition handbook: from oil dependency to local resilience. Totnes: Green Books.

Hopkins, R., 2011. The transition companion: making your community more resilient in uncertain times. Totnes: Green Books.

Hulme, M., 2009. Why we disagree about climate change? Cambridge: Cambridge University Press.

Hulme, M., 2010. Cosmopolitan climates: hybridity, foresight and meaning. Theory, Culture and Society, 27 (2/3), 267-276.

IPPR, 2010. Green streets: exploring the potential of community energy projects (interim report) [online]. Available from: http://www.ippr.org/publications/55/1795/green-streets-exploring-thepotential-of-community-energy-projects-interim-report [Accessed 17 November 2013].

IPPR, 2011. Green streets, strong communities. Platt: IPPR. Published 05 July.

Irvine, S., 2009. Transitional demands. Red Pepper, 19 December.

Jackson, T., 2005. Motivating sustainable consumption: a review of evidence on consumer behaviour and behaviour change: a report to the Sustainable Development Research Network. Centre for Environmental Strategy, University of Surrey. Available from: https://www.c2p2online.com/ documents/MotivatingSC.pdf [Accessed 17 November 2013].

Jackson, T., 2009. Prosperity without growth: economics for a finite planet. London: Earthscan.

Jessop, B., 2002. Liberalism, neoliberalism and urban governance: a state-theoretical perspective. Antipode, 34 (3), 452-472.

Levitas, R., 2000. Community, utopia and new labour. Local Economy, 15 (3), 188-197.

Lovell, H. and MacKenzie, D., 2000. Accounting for carbon: the role of accounting professional organisations in governing climate change. Antipode, 43 (3), 704-730.

Macnaghten, P., 2006. Nature. Theory, Culture \& Society, 23 (2-3), 347-349.

Mason, K. and Whitehead, M., 2012. Transition urbanism and the contested politics of ethical place making. Antipode, 44 (2), $493-516$.

Massey, D., 2005. For space. London: Sage.

Middlemiss, L.K., 2009. The role of community-based organisations in stimulating sustainability practices among participants. Unpublished $\mathrm{PhD}$ thesis, Leeds University.

Mouzelis, N.P., 2008. Modern and postmodern social theorizing. Bridging the divide. Cambridge: Cambridge University Press.

Painter, J., 2006. Prosaic geographies of stateness. Political Geography, 25 (7), 752-774.

Raco, M. and Flint, J., 2001. Communities, places and institutional relations: assessing the role of area-based community representation in local governance. Political Geography, 20 (5), $585-612$

Raco, M. and Imrie, R., 2000. Government and rights and responsibility in urban policy. Environment and Planning A, 32 (12), 2187-2204.

Randall, R., 2009a. Carbon conversations: six meetings about climate change and carbon reduction. Cambridge: Cambridge Carbon Footprint.

Randall, R., 2009b. Loss and climate change: the cost of parallel narratives. Ecopsychology, 1 (3), $118-129$.

RESOLVE, 2008. Community action: a force for social change? Some conceptual observations (Peters, M. \& Jackson, T.) Working Paper Series 01-08 [University of Surrey]. Available from: http:// resolve.sustainablelifestyles.ac.uk/publications/communityactionaforceforsocialchange [Accessed 17 November 2013].

RESOLVE, 2008. Community action: a force for social change? (Peters/Jackson) Working Paper $01-08$.

Rip, A. and René, K., 1998. Technological change. In: S. Rayner and L. Malone, eds. Human choice and climate change, Vol 2 Resources and Technology. Washington, DC: Batelle Press, 327-399.

Rose, N., 1996. The death of the social? Re-figuring the territory of government. Economy and Society, 25 (3), 327-356.

Royal Society for Arts (RSA) Report, 2010. Connected communities: how social networks power and sustain the Big Society [online]. Available from: http://www.thersa.org/projects/connectedcommunities [Accessed 17 November 2013].

Schreuer, A., 2010. Energy cooperatives as a social innovation process in the energy sector: a conceptual framework for further research. Proceedings of the 9th annual IAS-STS conference "Critical issues in science and technology studies" 3rd-4th May 2010, Graz, Austria. 
Scott-Cato, M. and Hillier, J., 2010. How could we study climate-related social innovation? Applying Deleuzean philosophy to transition towns. Environmental Politics, 19 (6), 869-887.

Scottish Government, 2011. Review of the climate challenge fund. Scottish Government Social Research, 1-116. Available from: http://www.scotland.gov.uk/Resource/Doc/352709/0118663. pdf [Accessed 17 November 2013].

Seyfang, G., 2009. The new economics of sustainable consumption: seeds of change. Basingstoke: Palgrave Macmillan.

Seyfang, G. and Smith, A., 2007. Grassroots innovations for sustainable development: towards a new research and policy agenda. Environmental Politics, 16 (4), 584-603.

Seyfang, G. Haxeltine, A., Hargreaves, T., and Longhurst, N., 2010. Energy and communities in transition - towards a research agenda on agency and civil society in sustainability transitions. CSERGE Working Paper EDM 10-13. Available from: http://www.cserge.ac.uk/sites/default/ files/edm_2010_13_0.pdf [Accessed 17 November 2013].

Shove, E., 2003. Comfort, cleanliness and convenience: the social organisation of normality. Oxford: Berg.

Smith, N., 1984. Uneven development: nature, capital and the production of space. Oxford: WileyBlackwell.

Smith, A., 2005. The alternative technology movement: an analysis of its framing and negotiation of technological development. Research in Human Ecology, 12 (2), 106-119.

Stewart, F., Parry, S., and Murphy, J., 2013. Sustainable communities as a policy frame: the case of the climate challenge fund in Scotland. Innogen Working Paper no. 107, Feb 2013 [online]. Available from: http://www.genomicsnetwork.ac.uk/media/Innogen\%20Working\%20Paper\%20107.pdf [Accessed 17 November 2013].

Swyngedouw, E., 2005. Governance innovation and the citizen: the Janus face of governance-beyondthe-state. Urban Studies, 42 (11), 1991-2006.

Toke, D., Breukers, S., and Wolsink, M., 2008. Wind power deployment outcomes: how can we account for the differences? Renewable and Sustainable Energy Review, 12 (4), 1129-1147.

Unruh, 2002. Escaping carbon lock-in. Energy Policy, 30 (4), 317-325.

Verbong, G. and Geels, F., 2007. The ongoing energy transition: lessons from a socio-technical, multilevel analysis of the Dutch electricity system (1960-2004). Energy Policy, 35 (2), 1025-1037.

Walker, G., 2008. What are the barriers and incentives for community-owned means of energy production and use? Energy Policy, 36 (12), 4401-4405.

Walker, G. 2011. The role for 'community' in carbon governance. Wiley Interdisciplinary Reviews: Climate Change, 2 (5), 777-782.

Wallace, A., 2010. New neighbourhoods, new citizens? Challenging "community" as a framework for social and moral regeneration under new labour in the UK. International Journal of Urban and Regional Research, 34 (4), 805-819.

Warren, C.R. and Birnie, R.V., 2009. Re-powering Scotland: wind farms and the "energy or environment?” Debate. Scottish Geographical Journal, 125 (2), 97-126.

Williams, 1983. "Community" In: Keywords. London: Fontana. 